\title{
ENGENDERING THE REFUGEE CRISIS IN EUROPE
}

\begin{abstract}
Since the beginning of 2015, Europe has been facing a refugee crisis where thousands of people have risked their lives to reach European soil. European politicians and media labelled this crisis as a new issue for the EU, not because the crisis was an entirely new phenomenon, but due to the staggering increase in the number of refugees from conflict areas, most notably Syria, Afghanistan, Eritrea, and Somalia. In 2015 alone, over one million refugees sought asylum in Western Europe. The majority of these had travelled through Turkey, Greece, and the Western Balkans to reach their final destination. The perils they faced during that route have been recorded in many of the reports by the International organization for migration (IOM), the UN Security Council, and many other organizations and departments involved in the crisis. In spite of all this, very little attention has been paid to the gender dimension of this refugee crisis, the problems women have been facing, the treatment they have been given, and the steps taken to help protect their human rights above all, but also their rights to services directly meeting their specific needs.
\end{abstract}

Keywords: REFUGEE CRISIS, GENDER, VIOLENCE, SEXUAL VIOLENCE, EU, POLICIES

\section{Introduction}

The culmination of the refugee crisis in the Mediterranean is the result of the increasing restrictions to legal channels through which migrants could reach European borders on the one hand, and the increase of the intensity of conflicts in certain regions in the Middle East and Africa, on the other hand. Millions of people have left their countries seeking salvation in more secure areas, and above all in European countries. Among the refugees, there was an enormous number of women and girls who, fleeing their homes, sought safer living environments for themselves and their children. As difficult as it is to admit it, gender and sex are closely linked to lack of safety during migrations, especially in a refugee crisis of this magnitude. The strength of that connection will depend on several factors, primarily on the social and economic position of women in their home country and gender relations in the same. Gender and sex influence and shape each phase of the migration process, including risks, vulnerability, needs, available opportunities and resources, etc. Consequently, gender and sex will have an impact on 
the human experience in such a crisis, and understanding that influence is essential in addressing the gender-specific protection and assistance, prevention and responses to the new forms of gender-based violence and building gender-specific capacities for response to the crisis caused by the mass waves of refugees.

\section{Gender statistics of the refugee crisis in Europe}

In spite of the fact that the refugee crisis that unfolded in the Mediterranean was only prominent in global media 2015, it was clear that there had been a growing number of migrants in the past few years trying to reach $\mathrm{Eu}$ rope through the Mediterranean. According to estimates by the UNHCR, in 2010, 8,500 persons from Syria alone have sought asylum in European countries, in 2013 their numbers increased sixfold, and in 2014 over 6 million people left Syria going to Jordan, Lebanon, Egypt, Turkey, and Iraq (UNHCR, 2016). Between March 2011 and December 2013, EU countries received 69,740 asylum applications from Syrian citizens, 41,695 of which were approved. However, this number is only $2.9 \%$ of the overall Syrian refugee population in that period. 14,7\% of all refugees in 2011, and 44,7\% in 2013 used smuggling routes to get to Greece or Italy (Fargues, 2014, 3). Although there are no data on the ratio of sexes of the migrants, it can be assumed that it is a balanced ratio since the European Asylum Office reported that a large portion of the refugees are there with their families.

By the end of 2014, the number of refugees on European borders increased drastically, mostly due to conflicts in Afghanistan, Somalia, and Eritrea. In the first eight months of 2015, 381,412 migrants crossed the Mediterranean, 50\% of which were from Syria (UNHCR, 2016), and 2,366 migrants died attempting to cross the sea (IOM 2015). The European Council held a special meeting on the crisis, during which meeting the severity of the situation was assessed and measures were promised to strengthen European presence in the region, to assist in the fight against human smuggling, and strengthening international solidarity and accountability. This would mean that Europe is acknowledging that it is facing a crisis due to the flow of migrants into the Mediterranean, most of which are fleeing conflict areas (unlike in the past years where economic migrants were the majority). The statement of the International institute for strategic research from May 2016 confirms the fact that Europe was facing a refugee crisis, stating that the number of migrants fleeing from armed conflicts has increased by $40 \%$ compared to 2013. The migrant route through Greece was mostly used by Syrian, Afgha$\mathrm{ni}$, and Iraqi refugees, and after the border of Greece and Turkey closed, refugees diverted their efforts towards Turkey and the maritime routes. According to UNHCR statistical data, from June to December 2015, 856,723 refugees entered Greece, whereas in January 2016 that number was 67,415. In the 
same period, 153,842 persons used the migrant route to the Italian border, and 5,237 in January 2016. The gender statistics shows an increase in the number of women-refugees: from June 2016 when they were 13\% of the entire refugee population, to January 2016 when there were $20 \%$ women-refugees (UNHCR, 2016). Representatives of MSF (Médecins Sans Frontières) in Athens stated that there is no accurate gender statistics for refugees arriving to Greece, but that the number of women is constantly on the rise and was estimated at around $20-30 \%$.

At the beginning of 2016, the number of women who migrated to Europe from conflict-ridden areas rose drastically. In February 2016 the UN Refugee agency published data according to which for the first time, the number of women and children (54\%) surpassed the number of men, and according to the Council of Europe, $60 \%$ of refugees arriving to Europe in March 2016 were women and children. The estimate of the European parliament and the Committee on women's rights and gender equality is similar. In a Draft-resolution on the situation of women-refugees and asylum seekers in the EU (2015/2325(INI)), the Committee states that from January to November 2015, around 900,000 persons reached European borders through the Mediterranean, 38\% of which are women and children, and in January 2016, this number rose to $55 \%$. The study of the International Organization for $\mathrm{Mi}$ gration (IOM) has shown that the percentage of women and girls in this refugee crisis depends on the region they come from and the severity of the conflict in that region, but it is certainly equal to the percentage of men $(\mathrm{C}$ ) 106/INF/8/Rev.1).

\section{Experiences of women in the refugee crisis}

Gender is a form of social identity that is oftentimes the basis for discrimination which could be a threat to the safety and well-being of the person. Gender inequality increases the threat against women since most do not possess the power to respond by brute force and stop the violence and harassment. The lack of safety for women is even further increased during armed conflicts due to the ever increasing systematic attacks against civilians in the past century, and also due to the consequences women face when they decide to leave their homes and seek better lives in other countries. The refugee status is a typically gender-based experience, since up to $80 \%$ of all refugees worldwide are women and children (Yuval-Davis, 1997, 168). Regardless of whether they are still fleeing and traveling down a refugee route, or they are in a refugee camp, or in an urban environment, women-refugees are at constant risk of gender-based violence, kidnapping, exploitation, poverty, and disease. In the refugee camps where they stay, they have no support or financial aid, other than the charity of international relief organizations. Unfortunately, they are facing sexual violence and exploitation even at the 
hands of their 'protectors' - guardians of peace and humanitarian workers who sometimes supply the human trafficking market with these refugee women, or sexually exploit them for a service.

The refugee crisis in the Mediterranean showed that nothing has changed regarding the experiences of women refugees, since gender and sex influenced every step of the process. Many women paid the price of freedom with the violence they endured. In their long journey, they rarely had access to clean and safe space for personal hygiene and rest, and information on where and how to find such a space were scarce. The research done by Mary Honeyball, a British member of the European Parliament and a rapporteur for the Committee on Women's Rights and Gender Equality, showed that women had to pay for their passports and other services by sex, which was a horrible experience. They were also subject to violence at the hands of human smugglers, local authorities, other refugees, and persons collaborating with human smugglers. For women who travelled alone or with children, there was danger even from police and the armies at the borders, especially the Turkish border (Freedman, 2016). Still, the greatest danger they could have faced was threatening their lives. If there ever was a time when migrant death at sea was a tragedy, in this refugee crisis it was a daily occurrence, and it was the result of the aggressive border managements by European institutions. In January 2016, more than 360 persons perished in the Mediterranean, one third of which were women and children. According to the UN Report on the refugee crisis, 4,579 persons lost their lives attempting to cross the Mediterranean from Libya, most of whom were women and children. In November 2017, over 26 West-African girls ages 14 to 18 years were found dead in the Mediterranean. This is simply some of the data demonstrating how much women risked their lives traveling to European borders, even though there is no accurate statistics on the number of victims during the refugee crisis.

The uncertainty in their lives continues even at the refugee camps and other temporary facilities, waiting to be granted permits to proceed and living in extremely difficult conditions. Some of the problems they face are lack of basic health care, living arrangements forcing them to live with unknown men, lack of personal hygiene opportunities, lack of privacy and rest, lack of bare necessities such as food, water, clothing, electricity, mattresses, etc. In such conditions, their safety and well-being is at danger. Many women faced double insecurity, since their husbands, instead of protect them, harassed them further, and they found themselves in a hopeless situation with no way out. The lack of adequate conditions to receive and accommodate refugees resulted in increased likelihood of violence, including sexual violence, and severely decreases their physical safety. In compliance with the UNICEF report of February 2017, a staggering 75\% of polled women and children refugees from North Africa said that they had been victims to violence during 
their journey to Europe, and 50\% said they had been victims of multiple cases of sexual violence. In March 2016, Amnesty International reported a large number of sexual violence against Syrian women refugees in Lebanon and UNHCR confirmed a large number of reported cases of sexual violence against women and girls refugees along the Mediterranean route, committed even by guards in refugee centres, including in European countries. UNHCR also expressed their concern regarding the lack of awareness by authorities and humanitarian organizations of this situation, the lack of data on these crimes and the reluctance of victims to report the crime. Sexual violence against women resulted in grave physical, psychological, cultural, and other consequences, but by far the most severe consequences are pregnancy and sexually-transmitted diseases, which in the absence of adequate healthcare could be fatal. The lack of safe routes to their final destinations in Europe and the vulnerability and specific needs of women and girl's refugees certainly play to the advantage of criminal networks, so kidnapping, forced prostitution, and human trafficking, especially trafficking in women and children, pose a constant threat in all refugee crises.

Detaining female refugees, including pregnant women, is another cause for concern. The number of migrant detainment centres in Europe has increased drastically, and women are held in custody in the same cells as men who are not their relatives. Centres initially purposed as reception and registration of refugees in Greece and Italy turned into detainment centres fraught with risks to the safety and well-being of the female refugees. The court in Strasbourg ruled infringements of the European Human Rights Convention in multiple cases die to sub-standard detainment conditions of women refugees, including pregnant women (Commissioner for Human Rights, 2016).

Abuse and discrimination persist even in asylum-seeking procedures in European countries, this time by the authorities. Women and girls seeking asylum have specific needs for protection, in particular they are unaccompanied, pregnant, have a disability, or fall within a vulnerable category for other reasons. Oftentimes, they come from regimes that oppress women, do not recognize them as equal to men, tolerate violence against them, practice genital mutilation, etc. If a woman is accompanied by a man, her legal status depends on the person accompanying her, regardless of whether it is a husband, fiancé, brother, or father. Either way, the quality and form of decisionmaking in asylum cases differ in cases regarding men and those regarding women. Modern research suggest that it happens very often that the man seeks asylum and protection for his wife and children, which is the result of the gender barriers in access to protection which omen refugees are facing. Due to the traditionally unequal division in labour in their countries, these women are often left without financial and administrative independence and without the possibility to leave the country by themselves and seek asy- 
lum. The likelihood of women having enough evidence to back an asylum claim is a lot lower, due to their subordinate economic, political, and social status in the country of origin. These women who have suffered trauma can rarely talk about it, and many NGOs are reporting a culture of disbelief in the decision-makers of their asylum claims, which is why only documented cases are taken into consideration. In the lack of such evidence, women face a number of specific challenges in the hearing process, thus experiencing multi-faceted gender-based discrimination. This furthers the chances of them being socially excluded. Asylum seekers in Europe live on an income far below the poverty line. This is especially difficult for pregnant women and new mothers who are not receiving any financial assistance. Even after their status as asylum seekers has been approved, women face employment and welfare barriers, including a lack of access to child care. In order to stay in the countries where they have arrived, women oftentimes have to accept illegal employment in degrading conditions. On the other hand, the rise of right-populism and extremism in Europe puts women refugees in a further risk of racist discrimination, discrimination and violence (European Parliament, 2015/2325/INI).

Based on data from UN Women on the condition of women in the refugee crisis in Europe, their specific needs and vulnerability were rarely taken into consideration within the frameworks of humanitarian planning and implementing of activities for protection and assistance for refugees. The results of a research conducted with 48 organizations and entities involved in humanitarian activities, have shown that the specific needs, the dignity, and right to protection of women and girls have not been fully fulfilled and provided. The response planning, the services, and protection capacities were insufficient to meet the needs of women and girl's refugees. The organization especially highlights the lack of support including monitoring and prevention against sexual violence, psychosocial support and trauma counselling, health and reproductive services, separate housing for women, as well as local capacities for registration in shelters and transit centres. Another weak point has been identified in the lack of information on transit routes, camps, services available to them, including legal services, and other necessary information (UN Women - Europe and Central Asia, 2016).

\section{New EU policies on improving the condition and rights of women refu- gees}

Taking into consideration the gender dimension of the refugee crisis in Europe, the specific position and needs of women refugees and asylum seekers, as well as the numerous reports on their experiences relating poor management of the crisis (including the Report of the Committee on rights of women and gender equality - A8-0024/2016), the European Parliament 
produced the Report on situation of women refugees and asylum seekers in the EU (2015/2325(INI)), focusing on suggestions to improve the treatment of women refugees in all stages of the crisis.

The first step in providing greater security for women refugees is making safe and legal refugee and asylum routes accessible, in order to prevent smuggling operations and thus decrease the number of casualties, pressures, and human rights infringements, including sexual 'favours' as a mean to pay for a service.

The second step in providing security for women refugees in engendering the refugee status, which encompasses: broader reforms of the migration and asylum EU policies; developing programs for improving asylum procedures that are sensitive to the needs of women; granting asylum on the grounds of having suffered gender-based violence; identifying and communication with vulnerable categories of women who are seeking asylum, and preventing any kind of violence against them; synchronizing asylum-seeking procedures in EU member-states with the guidance of the UNHCR for international protection; revising the financing and adapting of Daphne and Odysseus to certain situations which would help protect women refugees; avoiding rash decisions in asylum-seeking cases and taking into considerateon the dangers women asylum-seekers would face if their applications are rejected and they are forced to go back to their countries of origin; while assessing the claims of female asylum applicants, cultural, social, and psychological profiles need to be taken into considerations; increasing the availability of information on asylum procedures, rights of women seeking asylum and the specific services that are available to them in that process; increasing police and judicial cooperation of EU member-states with Europol, Frontex, Eurojustice and the European Asylum Support Office (EASO) to ensure a more efficient persecution of smugglers and human trafficking targeting migrants.

The third step refers to the right of women refugees to ask for a woman to conduct the interview and a woman interpreter during interviews in the asylum procedure. The EU is recommending a development program for a new module for gender training in asylum policies.

The fourth step refers to the reception and detaining asylum-seekers in the EU, calling for authorities to avoid detaining and establish open and humane procedures for reception of asylum-seekers, including safe, dignified and human-rights compatible treatment. The European parliament is calling for the development of alternatives of detention, but in cases where detainment is necessary, it should not be used for a long period, since it is harmful to vulnerable groups.

The fifth step refers to the social inclusion and integration of women refugees and asylum-seekers, calling for EU countries to develop and imple- 
ment specific measures to facilitate their access to the labour market. These measures include access to education, non-formal education and cultural exchange, language lessons, healthcare, employment adequate to their skills and qualifications, as well as housing which will meet their needs (2015/2325 (INI)).

\section{Conclusion}

The refugee crisis in Europe has exposed the failure of EU memberstates to protect the refugees who came to Europe searching for a new life. The key acts from the Common European Asylum System (CEAS) failed to guarantee a consistent and gender-sensitive treatment for women who sought protection in Europe. In spite of the existence of legislature and policies designed to function acknowledging the gender dimension of the refugee crisis, the management of this crisis has severe shortcomings, mainly due to the fact that such policies were not effectively implemented. Each country should make it a priority to implement more humane migration and asylum policies, which also encompasses the securing of border crossings and refugee routes, guaranteeing easier access to asylum, improving the conditions of entry, encouraging an effective integration into host-countries, and ensuring a fair distribution of asylum seekers. When designing and implementing these policies, attention needs to be paid to women, girls, and children, especially those who are victims of violence. International organizations call for implementing a coordinated responsive system by countries to protect refugees and respond to gender-based violence during this refugee crisis. A coordinated action is needed to share the responsibilities and coordinate the actions of all international and national actors involved in responding to the crisis. The experiences in managing this crisis regarding protection of women-refugees should act as an incentive to coordinate the best policies in their treatment of womenrefugees in all stages of the refugee crisis. 


\section{References}

Citizens Association for Combating Trafficking in Human Beings and All Forms of Gender-Based Violence. (2016). The Women Helping Refugees Survive Europe's Migration Crisis, Athens.

Council of Europe Parliamentary Assembly Resolution 1765 (2010) on gender-related claims for asylum.

Council of Europe, Commissioner for Human Rights. (2016). Human Rights of Refugee and Migrant Women and Girls need to be better protected, Strasbourg.

European Parliament, Committee on Women's Rights and Gender Equality. (2016). Report on the situation of women refugees and asylum seekers in the EU 2014 - 2019. 2015/2325 (INI), A8-0024/2016.

Fargues, P. (2014). Europe Must Take on its Share of the Syrian Refugee Burden, but how?, Policy Brief 2014/1, Migration Policy Centre, Florence, European University Institute.

Freedman, J. (2016). Engendering Security at the Borders of Europe: Women Migrants and the Mediterranean Crisis. Journal of Refugee Studies, Vol. 29, No. 4, Oxford University Press.

Hanrahan, M. (2016). Refugee Crisis: Women, Children Report Sexual Violence, Abuse on Migration Trail, Says UN, http://www.nbcnews.com.30.01.2018.

International Organization for Migration. (2015). JOM Gender Equality Policy 2015 - 2019, Council 106 ${ }^{\text {th }}$ Session, C/106/inf/8/Rev.1.

Security and Tradition or Violence against Women? (2017). Istanbul Convention and the Universal Rights of Female Migrants, Copenhagen, 24. 11.2017.

UN Women - Europe and Central Asia. (2016). UN Women assesses the needs of Syrian women refugees in Serbia and FYR Macedonia, http://eca.unwomen.org/en/news/stories/2016/01, Пристапено на: 30.01 . 2018.

UNHCR. (2016). Risk for Women and Girls in the European Refugee and Migrant Crisis.

Women's rights and gender equality in Europe Report (2015) of the roundtable with human rights defended organized by the Office of the Council of Europe Commissioner for Human Rights, Vilnius.

Yuval- Davis Nira, (1997), Gender and Nation, Sage Publications, London, Thousand Oaks, New Delhi. 